International Journal of Civil Engineering and Technology (IJCIET)

Volume 9, Issue 10, October 2018, pp. 409-421, Article ID: IJCIET_09_10_042

Available online at http://www.iaeme.com/ijciet/issues.asp?JType=IJCIET\&VType=9\&IType $=10$

ISSN Print: 0976-6308 and ISSN Online: 0976-6316

OIAEME Publication

Scopus Indexed

\title{
GRAVITY MODEL APPROACH USING VECTOR AUTOREGRESSION IN INDONESIAN PLYWOOD EXPORTS
}

\author{
Anwar Sanusi, Rusiadi, M. Isa Indrawan, Irma Fatmawati, Ade Novalina, Samrin, \\ Andysah Putera Utama Siahaan, Saimara Sebayang, Marahadi Siregar, Ahmad Taufik \\ Universitas Pembangunan Panca Budi, Medan, Indonesia
}

\begin{abstract}
This study aims to detect the determinants of plywood exports in Indonesia based on the Gravity model. Problems that occur are related to inefficient and effective exports. The analytical method uses Vector Autoregression with a single equation using a gravity model to analyze the factors that influence the flow of Indonesian plywood trade. The assumption results using Vector Autoregression (VAR), shows the results of the relationship between GDP, POP, ER, $P, D t$ and Vol with lag 1, this can be concluded that by observing the $t$-statistics of each coefficient, the reciprocal relationship between the variables GDP, POP, ER, P, Dt and Vol are statistically significant. Another variable besides the variable itself that has the most significant contribution to GDP is the distance $t-1$. The variable that has the most significant contribution to the population other than the population itself is Price $(P) t-1$. The variable that has the most significant contribution to ER besides the ER variable itself is Population. The variable that has the most significant contribution to Price $(P)$ is the GDP variable. Other variables that have the most significant contribution to Distance (Dt) other than the Distance variable itself are variables of Indonesian Plywood Export Volume. Other variables that have the most significant contribution to Indonesia Plywood Export Volume in addition to the Indonesian Lapis Wood Export Volume variable itself are Population.
\end{abstract}

Key words: Vector Autoregression (VAR), Gravity Model, Export, Plywood.

Cite this Article: Anwar Sanusi, Rusiadi, M. Isa Indrawan, Irma Fatmawati, Ade Novalina, Samrin, Andysah Putera Utama Siahaan, Saimara Sebayang, Marahadi Siregar, Ahmad Taufik, Gravity Model Approach using Vector Autoregression in Indonesian Plywood Exports, International Journal of Civil Engineering and Technology (IJCIET) 9(10), 2018, pp. 409-421.

http://www.iaeme.com/IJCIET/issues.asp?JType=IJCIET $\&$ VType=9\&IType $=10$ 
Anwar Sanusi, Rusiadi, M. Isa Indrawan, Irma Fatmawati, Ade Novalina, Samrin, Andysah Putera Utama Siahaan, Saimara Sebayang, Marahadi Siregar, Ahmad Taufik

\section{INTRODUCTION}

A country's income greatly affects the country's development [1]-[8] The optimization process needs to be done on a big problem [9]-[12] Indonesia cannot be separated from international trade, such as an export and import activity. The existence of international trade can help in the process of carrying out all development efforts through prioritizing economic sectors that contain comparative advantages (availability of natural resources as a factor of production) in all countries. Comparative advantage is the superiority of a country to produce goods with a relatively lower cost than other countries [13]. Thus, in the range of 2001 to 2012 the Japanese market still dominated as Indonesian Plywood Export destination with a proportion of $45 \%$ of Indonesia's total plywood exports. Besides Japan, there is also a dominance of the goal of Indonesia's plywood exports being China (10\%), South Korea (8\%), and the United States. During the period 2001 to 2012, markets in the United States were able to accept Indonesia's plywood exports by $9 \%$ of Indonesia's total plywood exports to ten export destinations.

Indonesia together with Malaysia became a producer of processed wood products on the world market, especially for hardwood plywood for years [14]. Two components must be considered in international trade are exports and imports. Export is an activity to sell domestic goods/services abroad. Indonesia's exports in 2012 amounted to USD 188,146 million, oil and gas contributed, and non-oil and gas contributed USD 152,575 million. Plywood is one of the products resulting from the development of a downstream wood processing industry. However, in connection with this matter, this paper aims to determine the factors that can affect Indonesia's plywood exports to the leading destination countries, such as China, Japan, the United States, South Korea, Saudi Arabia, using the Gravity Model method. This Gravity Model method was chosen because by using this model it is possible to do a quantity based model approach. Indonesia plywood exports in 2015 were to China with a volume reaching 697.4 thousand tons, up to 14.9 percent from the previous year. Second, Japan with export volume reaching 546.8 thousand tons, down to 15.4 percent from 643.5 thousand tons in the previous year.

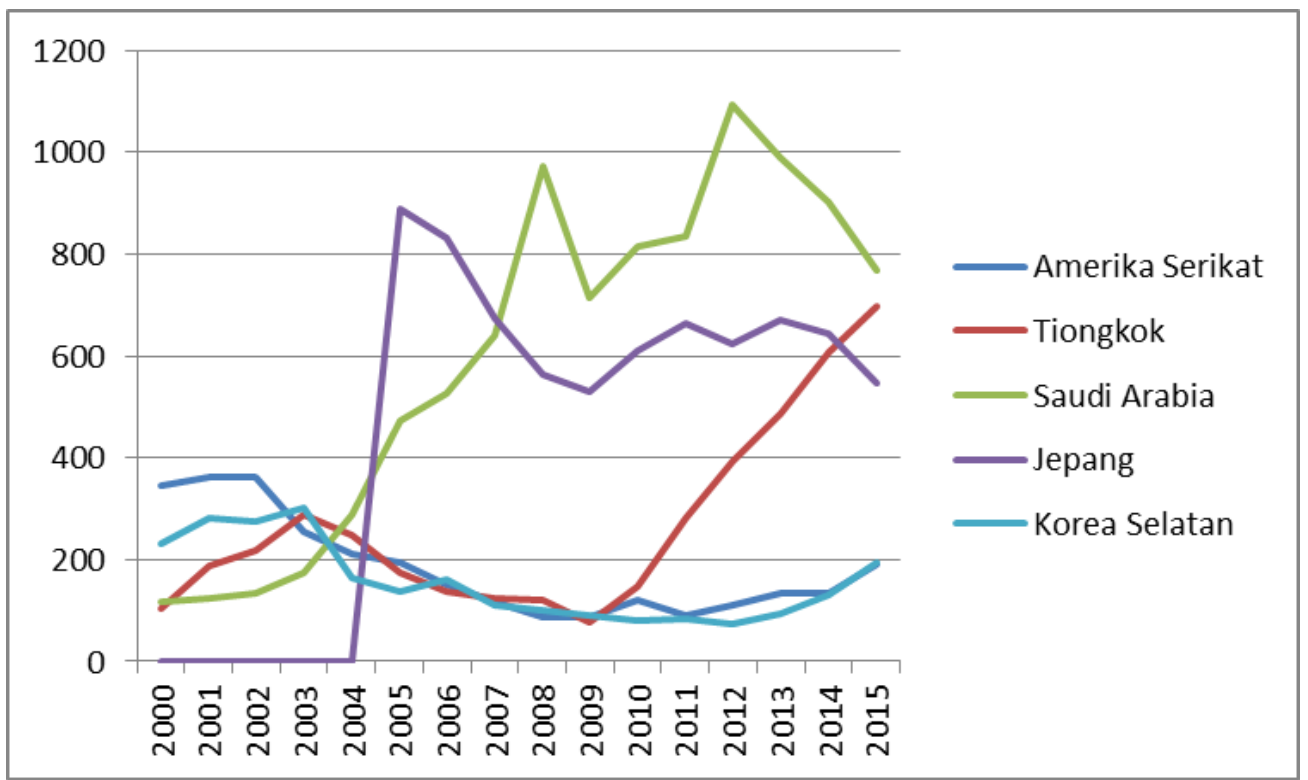

Source : www.bi.go.id [15] 
Gravity Model Approach using Vector Autoregression in Indonesian Plywood Exports

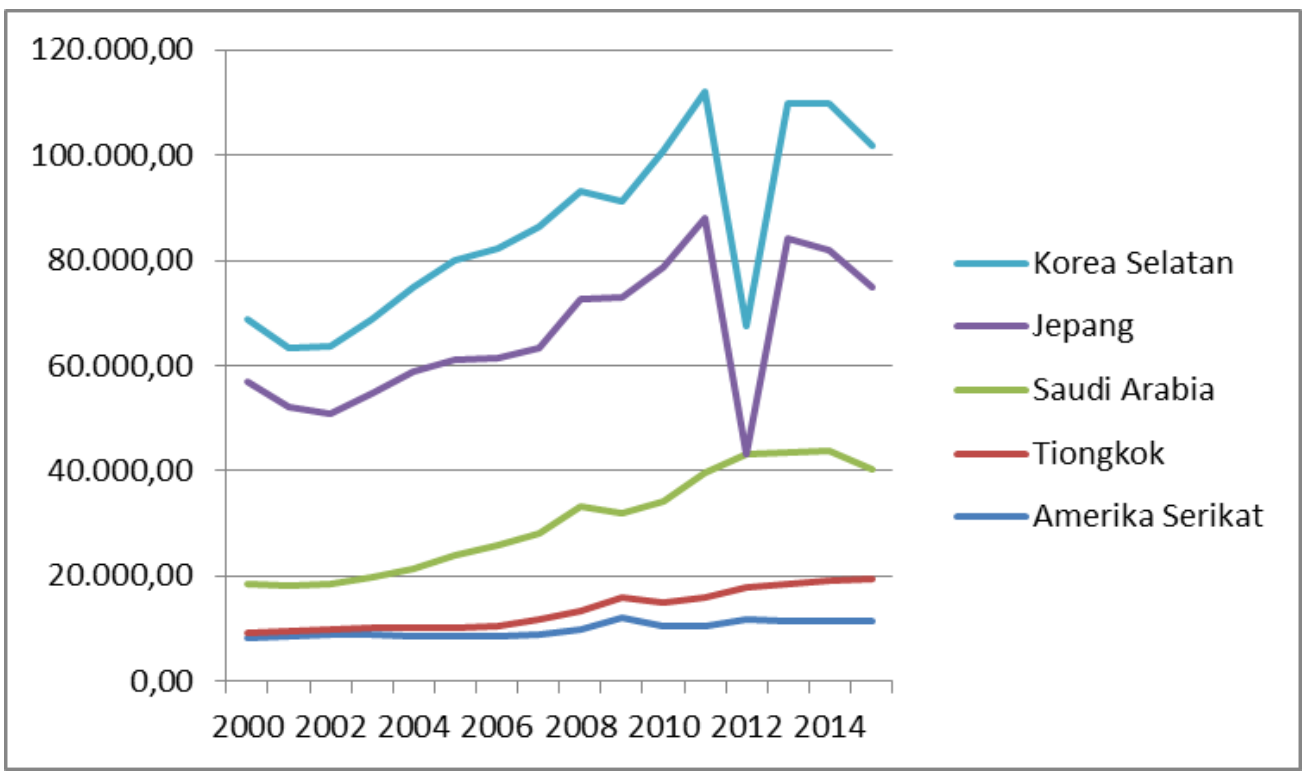

Source : www.worldbank.com [16]

Figure 1 Development of Export Volume and Value according to 5 main destination countries

Figure 1 describes the development of Indonesian exports to China, Saudi Arabia, Japan, South Korea, and the United States. The export value in 2015 of the five countries has experienced an increase and decrease. The decline occurred due to the impact of the global economic downturn that hit the world, while the increase occurred because of the many requests for processed plywood in other destination countries.

The Indonesian wood industry has an excellent opportunity to increase the share of plywood exports in the world which is still dominated by other countries. Indonesia has a good quality supply of raw materials. Therefore, this industry is supported by the relatively low production costs and the use of more efficient technology. Therefore, Indonesia has a high competitiveness in the world plywood market. This kind of industry in countries like America and Europe is pressed for the existence of the Indonesian plywood industry [17].

\section{THEORIES}

\subsection{Export and Gravity Model}

There are several definitions of exports according to experts, Exports are the expenditure of goods from Indonesian customs areas to be sent abroad by following the applicable provisions, especially regarding customs regulations [18]. According to Law No. 10 of 1995 concerning customs, export is an activity of issuing goods from the customs area, and goods that have been transported or will be loaded in the means of transport for removal from the customs area are considered to have been exported. Export activities can be divided into two, such as direct exports and indirect exports [19].

Indonesia primary export commodities are textiles and textile products (TPT), forest products, electronics, rubber and rubber products, oil palm and palm oil products, automotive, footwear, shrimp, cocoa, coffee and forest products such as logs and plywood. However, with the development of global trade, the international market is increasingly competitive so that Indonesia's ten main export commodities are diversified. Other commodities, for example, such as processed foods, jewelry, fish and fish products, handicrafts and spices, leather and leather products, medical equipment, essential oils, office equipment, and medicinal plants.

This model is used to analyze economic factors that affect trade between two countries. First time, the gravity model was used in the analysis of international trade, to analyze a flow of 
Anwar Sanusi, Rusiadi, M. Isa Indrawan, Irma Fatmawati, Ade Novalina, Samrin, Andysah Putera Utama Siahaan, Saimara Sebayang, Marahadi Siregar, Ahmad Taufik

trade between European countries. According to this model, goods exported from the country to the country are explained by the economic size of each country or Gross Domestic Product (GDP), the population of each country, the distance between countries [20]-[23].

Gravity models also present a more empirical analysis of trading patterns than more theoretical models [24]. This model also explains trade based on the distance between countries and the interaction between countries in the size of the economy, such as GDP and population. The background to the gravity model is that a larger and more wealthy country conducts foreign trade compared to smaller and weaker countries. The gravity equation model is the application of the balance of the world trade model [25]-[27] The gravity variables used in the equation include distance, price, and exchange rate. In conditions where demand and bidder are in an equilibrium position. The various components contained in the gravity model are economic factors that influence trade flows in destination countries and natural products that increase or maintain trade flows [28].

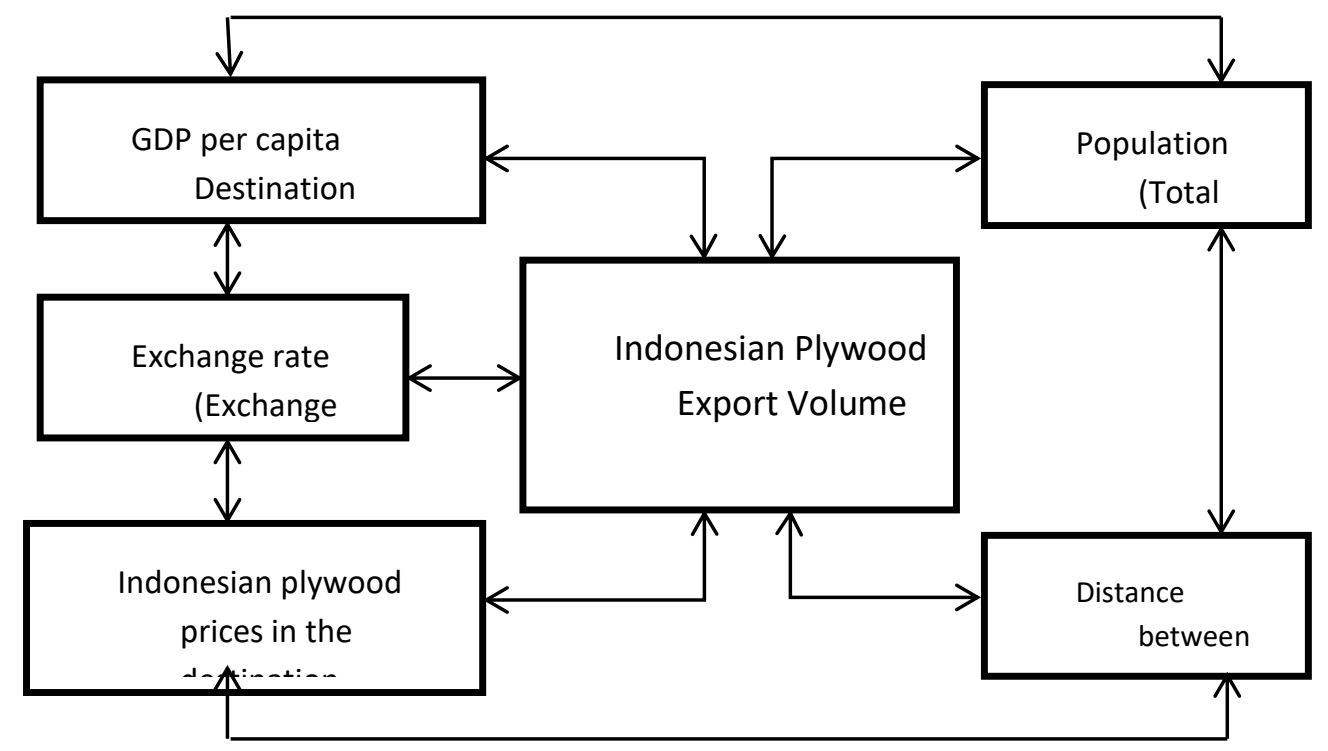

Figure 2 Conceptual framework

Hypothesis is a statement of the state of the population to be tested for truth using data or information collected through samples [29]-[31] The Gravity Model (GDP, volume, distance, price, exchange rate) can contribute to predicting Indonesia's plywood exports to the leading export destination countries. Saudi Arabia, China, Japan, South Korea, the United States as a country that contributes to increasing plywood exports in Indonesia with the Gravity Model approach (GDP, volume, distance, price, exchange rate) [32]-[34].

\section{METHODOLOGY}

The type of research conducted is quantitative with the support of the Vector Autoregression (VAR) model, which is used as a predictive analysis tool. This research proposes the title Analysis of the Gravity Model Approach in Predicting Indonesian Plywood Export Determinants. This test is conducted to find out whether there is a simultaneous (interrelated) relationship between variables, as an exogenous variable and an endogenous variable by entering a time element (lag). If the simultaneity between several variables is correct, then it can be said that the variables cannot be distinguished which are endogenous and which are exogenous variables. This test is conducted to find out whether there is a simultaneous (interrelated) relationship between the variable Gross Domestic Product (GDP), Population, 
Distance, Exchange Rate, and Price against the flow of international trade (Export) Plywood in several countries as an endogenous variable by including time elements (lag).

$$
\begin{gathered}
\text { Vol }=a 1 \mathrm{Vol}+a 2 \mathrm{GDP}+a 3 P O P+a 4 E R+a 5 P+a 6 D t+E 1 \\
G D P=a 7 \mathrm{Vol}+a 8 G D P+a 9 P O P+a 10 E R+a 11 P+a 12 D t+E 2 \\
P O P=a 13 \mathrm{Vol}+a 14 G D P+a 15 P O P+a 16 E R+a 17 P+a 18 D t+E 3 \\
E R=a 19 \mathrm{Vol}+a 20 \mathrm{GDP}+a 21 P O P+a 22 E R+a 23 P+a 24 D t+E 4 \\
P=a 25 \mathrm{Vol}+a 26 \mathrm{GDP}+a 27 P O P+a 28 E R+a 29 P+a 30 D t+E 5 \\
D t=a 31 \mathrm{Vol}+a 32 \mathrm{GDP}+a 33 P O P+a 34 E R+a 35 P+a 36 D t+E i j
\end{gathered}
$$

Where:

$\mathrm{Xij} \quad=$ Indonesian paper export volume to destination country (tons)

$\mathrm{Yj}=$ GDP per capita of destination country (US \$ / org)

$\mathrm{Nj}=$ Population of destination country (million)

Dij =Distance between Indonesia and destination country $(\mathrm{km})$

$\mathrm{Pj} \quad=$ Indonesian paper prices in the destination country (US \$ / ton)

Erj = Exchange rate of the destination country against the US Dollar (domestic / US \$)

Eij $\quad=$ Random error

\section{RESULT AND DISCUSSION}

\subsection{Test Results of Roots Unit (Stationarity) and Degree of Integration}

A stationary test can be carried out by unit root tests developed by Dickey Fuller (1981). An alternative to the Dickey-Fuller test is Augmented Dickey-Fuller (ADF) which attempts to minimize autocorrelation. This test contains a regression of the first differentiation of data regarding time against the lag of the variable, lagged difference terms, contingencies, and trend variables. To see stationarity using the DF or ADF test is done by comparing the $t=$ tau) statistics of the variable lag dependent variable with the critical value of DF or ADF in the table. Non-stationary data can cause smooth regression, so data stationarity tests are needed. The stationary test results of the variables in the study are shown in the table below. This study begins with a stationary test of the variables used in the study namely Gross Domestic Product of the destination country (importer), Population, Distance, Exchange Rate and Price and export volume Indonesia.

Table 1 Test results root units with levels

\begin{tabular}{|c|c|c|c|c|}
\hline Variable & $\begin{array}{c}\text { Augmented } \\
\text { Value of Dickey } \\
\text { Fuller }\end{array}$ & $\begin{array}{c}\text { Mc Kinnon's } \\
\text { Critical Value } \\
\text { at 1\% } \\
\text { Significance } \\
\text { Level }\end{array}$ & Prob & Conclusion \\
\hline Vol & -0.551986 & -3.610453 & 0.8697 & Not stationary \\
GDP & -2.259494 & -3.610453 & 0.1897 & Not stationary \\
POP & -1.713243 & -3.571310 & 0.4148 & Not stationary \\
ER & -0.013714 & -3.610453 & 0.9515 & Not stationary \\
P & -3.585810 & -3.571310 & 0.0096 & Stationary \\
Dt & -1.971206 & -3.571310 & 0.2982 & Not stationary \\
\hline
\end{tabular}

Source: Attachment Test Root Test Unit 
Anwar Sanusi, Rusiadi, M. Isa Indrawan, Irma Fatmawati, Ade Novalina, Samrin, Andysah Putera Utama Siahaan, Saimara Sebayang, Marahadi Siregar, Ahmad Taufik

The results of Augmented Dickey-Fuller test in TableTable 1 show that the data of all variables are not stationary except the Price variable $(\mathrm{P})$ as indicated by the Dickey-Fuller value of statistics below the critical value of Mc Kinnon at the $1 \%$ confidence level. Even in Appendix 3 shows that all data is not stationary at the level except the Price $(\mathrm{P})$ variable. The solution that can be done for non-stationary data is to create new variables in the first difference (called DGDP, DPOP, DER, DDt, and DVol except for the price variable (P)), then the ADF test is done again.

\subsection{Vector Autoregression (VAR)}

VAR estimation is supported by the use of lag, where the value of Akaike Information (AIC) and Schwarz Information Criterion (SIC) are the smallest among lags as guidelines for determining lag length. Based on the determination of lag length, it is known that the primary lag or lag 1 of the AIC value and the SIC value is the best value so that it says lag 1 is the best compared to other models and this study uses lag 1 . The assumption of lag one is determined by lag stability structure by using Inverse Roots of AR Characteristic Polynomial and Parsimony principle. Where the value of structure lag in lag 1 is stable, then lag 1 . The result of VAR analysis can be seen in the following table.

Table 2 VAR Estimation Results with Lag 1 Base

\begin{tabular}{|c|c|c|c|c|c|}
\hline \multicolumn{6}{|c|}{ Vector Autoregression Estimates } \\
\hline \multicolumn{6}{|c|}{ Date: $07 / 12 / 18$ Time: $07: 50$} \\
\hline \multicolumn{6}{|c|}{ Sample (adjusted): 279} \\
\hline \multicolumn{6}{|c|}{ Included observations: 78 after adjustments } \\
\hline \multicolumn{6}{|c|}{ Standard errors in ( ) \& t-statistics in [ ] } \\
\hline & VOLUME & GDP & ER & PRICE & POPULATION \\
\hline \multirow[t]{3}{*}{ VOLUME(-1) } & 0.067243 & -0.170026 & -0.004914 & -0.008160 & -600.2927 \\
\hline & $(0.12070)$ & $(0.54913)$ & $(0.01647)$ & $(0.01291)$ & $(2274.10)$ \\
\hline & {$[0.55712]$} & {$[-0.30963]$} & {$[-0.29832]$} & {$[-0.63198]$} & {$[-0.26397]$} \\
\hline \multirow[t]{3}{*}{ GDP(-1) } & 0.002835 & -0.033514 & 0.004188 & 0.003106 & 109.6269 \\
\hline & $(0.02564)$ & $(0.11665)$ & $(0.00350)$ & $(0.00274)$ & $(483.089)$ \\
\hline & {$[0.11057]$} & {$[-0.28731]$} & [1.19700] & [ 1.13245] & {$[0.22693]$} \\
\hline \multirow[t]{3}{*}{ ER(-1) } & -0.509225 & -0.706715 & 0.852415 & -0.040893 & 2424.888 \\
\hline & $(0.47865)$ & $(2.17767)$ & $(0.06532)$ & $(0.05121)$ & (9018.43) \\
\hline & {$[-1.06387]$} & {$[-0.32453]$} & [ 13.0497] & {$[-0.79861]$} & {$[0.26888]$} \\
\hline \multirow[t]{3}{*}{ PRICE(-1) } & 0.925894 & 10.20004 & 0.118381 & 0.901106 & -16065.86 \\
\hline & $(0.83951)$ & $(3.81939)$ & $(0.11456)$ & $(0.08981)$ & $(15817.3)$ \\
\hline & [ 1.10290] & [2.67060] & [1.03331] & [ 10.0336] & {$[-1.01571]$} \\
\hline \multirow[t]{3}{*}{ POPULATION(-1) } & $-1.76 \mathrm{E}-06$ & $-1.37 \mathrm{E}-05$ & $-3.19 \mathrm{E}-07$ & $-1.15 \mathrm{E}-07$ & 0.914650 \\
\hline & $(2.6 \mathrm{E}-06)$ & $(1.2 \mathrm{E}-05)$ & $(3.5 \mathrm{E}-07)$ & $(2.8 \mathrm{E}-07)$ & $(0.04881)$ \\
\hline & {$[-0.67971]$} & {$[-1.16243]$} & {$[-0.90202]$} & {$[-0.41615]$} & [18.7409] \\
\hline \multirow[t]{3}{*}{$\mathrm{C}$} & 3560.736 & 4529.931 & 275.0147 & 393.7366 & 61967794 \\
\hline & $(2143.95)$ & $(9754.06)$ & $(292.579)$ & $(229.356)$ & $(4.0 \mathrm{E}+07)$ \\
\hline & [ 1.66083] & [0.46441] & [0.93997] & [ 1.71670] & [1.53406] \\
\hline R-squared & 0.534903 & 0.180602 & 0.872246 & 0.769060 & 0.844179 \\
\hline Adj. R-squared & 0.332117 & 0.123699 & 0.863374 & 0.753023 & 0.833359 \\
\hline Sum sq. resids & $9.04 \mathrm{E}+09$ & $1.87 \mathrm{E}+11$ & $1.68 \mathrm{E}+08$ & $1.03 \mathrm{E}+08$ & $3.21 \mathrm{E}+18$ \\
\hline S.E. equation & 11202.25 & 50965.41 & 1528.738 & 1198.397 & $2.11 \mathrm{E}+08$ \\
\hline F-statistic & 0.520787 & 3.173868 & 98.31619 & 47.95393 & 78.01401 \\
\hline Log likelihood & -834.8174 & -952.9899 & -679.4670 & -660.4773 & -1602.634 \\
\hline Akaike AIC & 21.55942 & 24.58949 & 17.57608 & 17.08916 & 41.24703 \\
\hline Schwarz SC & 21.74070 & 24.77077 & 17.75736 & 17.27045 & 41.42831 \\
\hline
\end{tabular}


Gravity Model Approach using Vector Autoregression in Indonesian Plywood Exports

\begin{tabular}{|l|c|c|c|c|c|}
\hline Mean dependent & 4140.041 & 23634.69 & 3388.038 & 2664.090 & $3.12 \mathrm{E}+08$ \\
\hline S.D. dependent & 11026.57 & 54443.85 & 4135.861 & 2411.418 & $5.17 \mathrm{E}+08$ \\
\hline \multicolumn{2}{|l|}{} & & & & \\
\hline Determinant resid covariance (dof adj.) & $2.32 \mathrm{E}+46$ & & & \\
\hline Determinant resid covariance & $1.55 \mathrm{E}+46$ & & & \\
\hline Log likelihood & -4701.405 & & & \\
\hline Akaike information criterion & 121.3181 & & & \\
\hline Schwarz criterion & 122.2245 & & & \\
\hline
\end{tabular}

Based on the results of the research shown on the basis of lag $=1$, it can be seen that there is a relationship between GDP, POP, ER, P, and Vol with lag 1, it can be concluded that by observing the t-statistics of each coefficient, reciprocal relationships between the variables GDP, POP, ER, P, and Vol are statistically significant. The estimated results of the equation that occur are as follows:

$$
\begin{aligned}
& \text { VOLUME }=C(1,1) * \operatorname{VOLUME}(-1)+C(1,2) * \mathrm{GDP}(-1)+\mathrm{C}(1,3) * \mathrm{ER}(-1)+\mathrm{C}(1,4) * \mathrm{PRICE}(-1)+ \\
& C(1,5) * \text { POPULATION }(-1)+C(1,6) \\
& \mathrm{GDP}=\mathrm{C}(2,1) * \operatorname{VOLUME}(-1)+\mathrm{C}(2,2) * \mathrm{GDP}(-1)+\mathrm{C}(2,3) * \mathrm{ER}(-1)+\mathrm{C}(2,4) * \mathrm{PRICE}(-1)+ \\
& C(2,5) * \text { POPULATION }(-1)+C(2,6) \\
& \text { POPULATION }=\mathrm{C}(5,1) * \operatorname{VOLUME}(-1)+\mathrm{C}(5,2) * \mathrm{GDP}(-1)+\mathrm{C}(5,3) * \mathrm{ER}(-1)+\mathrm{C}(5,4) * \mathrm{PRICE}(-1)+ \\
& C(5,5) * \text { POPULATION }(-1)+C(5,6) \\
& \mathrm{ER}=\mathrm{C}(3,1) * \operatorname{VOLUME}(-1)+\mathrm{C}(3,2) * \mathrm{GDP}(-1)+\mathrm{C}(3,3) * \mathrm{ER}(-1)+\mathrm{C}(3,4) * \mathrm{PRICE}(-1)+ \\
& C(3,5) * \text { POPULATION }(-1)+C(3,6) \\
& \text { PRICE }=\mathrm{C}(4,1) * \operatorname{VOLUME}(-1)+\mathrm{C}(4,2) * \mathrm{GDP}(-1)+\mathrm{C}(4,3) * \mathrm{ER}(-1)+\mathrm{C}(4,4) * \operatorname{PRICE}(-1)+ \\
& \mathrm{C}(4,5) * \text { POPULATION }(-1)+\mathrm{C}(4,6)
\end{aligned}
$$

Based on the results of the Vector Autoregression analysis it is known that the previous variables also affect. Where it can be shown that past variables ( $t-1)$ have a significant effect on themselves and other variables. From the estimation results above and the explanation turns out the reciprocal relationship between the variables Gross Domestic Product (GDP), Population, Exchange Rate (ER), Price (P), and Indonesian Paper Export Volume (Vol) becomes increasingly apparent and thus the hypothesis is reciprocal relations between Gross Domestic Product (GDP), Population, Exchange Rate (ER), Price (P), and Indonesian Paper Export Volume (Vol) as the variables observed in this study are proven. The VAR model is by the expectations of Indonesia's Paper Export Volume in the future; it can be shown in the trend of several variables that fluctuate.

The results show that all other variables in the study did not respond one standard deviation from Lapis Indonesia Wood Export Volume (Vol), in period 1 of 11202.25. In period 2, where one standard deviation from Vol is 990.8213 above the average positive response by GDP is 172.1881, Price (P) 707.1124. Then responded negatively by ER 82.10758, and Population -357.3248. In period 10 (long-term) one standard deviation of Volume (Vol) 68.94796 above the average responded positively by Price (P) 206.6555. Then it responded negatively by GDP -16.90285, and ER -213.9818, and Population -115.3227. Based on the results of the standard deviation division response from Vol it was concluded that there was a change in the influence of each standard deviation of each variable which was initially favorable to negative and vice versa which was initially negative positive, both in period 2 and period 10. 
Anwar Sanusi, Rusiadi, M. Isa Indrawan, Irma Fatmawati, Ade Novalina, Samrin, Andysah Putera Utama Siahaan, Saimara Sebayang, Marahadi Siregar, Ahmad Taufik

Table 3 Impulse Response Function of Volume

\begin{tabular}{cccccc} 
Period & VOLUME & GDP & ER & PRICE & POPULATION \\
\cline { 5 - 6 } 1 & 11202.25 & 0.000000 & 0.000000 & 0.000000 & 0.000000 \\
2 & 990.8213 & 172.1881 & -82.10758 & 707.1124 & -357.3248 \\
3 & 230.3410 & 57.99614 & -111.6553 & 681.7146 & -347.4537 \\
4 & 159.3438 & 40.77947 & -145.8312 & 592.8914 & -307.3598 \\
5 & 137.9872 & 25.82487 & -171.6346 & 509.3062 & -268.2088 \\
6 & 121.4564 & 13.62211 & -190.3841 & 433.9663 & -231.8458 \\
7 & 106.4720 & 3.487375 & -203.0941 & 366.6058 & -198.4288 \\
8 & 92.76711 & -4.829825 & -210.7189 & 306.6488 & -167.9255 \\
9 & 80.27769 & -11.55817 & -214.1010 & 253.5182 & -140.2588 \\
10 & 68.94796 & -16.90285 & -213.9818 & 206.6555 & -115.3227 \\
\hline \hline
\end{tabular}

Source: Data processed with Eviews
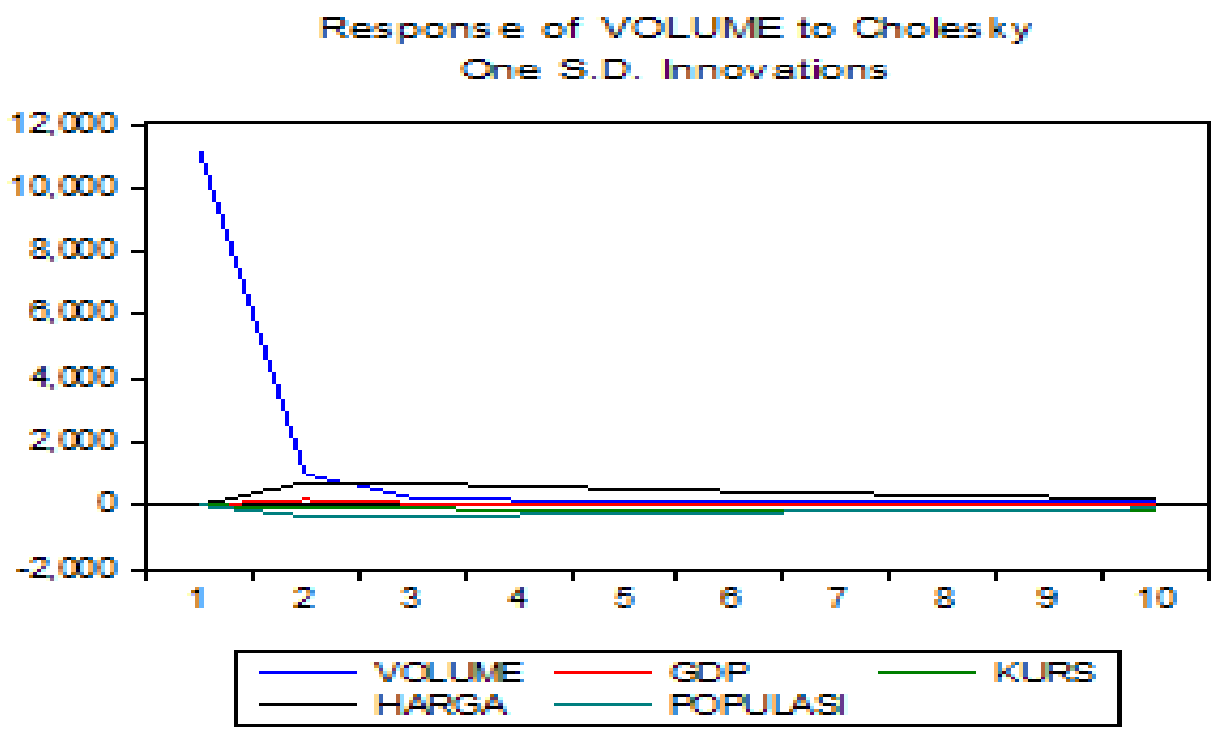

Figure 3. Vol variable response to changes in other variables

\subsection{Variance Decomposition GDP}

Table 4 explains that the GDP variable itself explains GDP in period 1, the estimated total variance error $(99.99 \%)$, and Vol variable is $(0.007 \%)$, while other variables are ER, P, POP does not respond at all, where the variable response it only appears in the 2 nd period. In period 2 all variables are affected. In period 10 the prediction of the dominant variance error is explained by the variable GDP $(84.24 \%)$ which is explained by the GDP itself. The other variable that most influences GDP as a policy variable other than GDP itself is $\mathrm{P}$ at $4.05 \%$, then ER is $1.66 \%$, while the smallest affects Vol by $0.01 \%$, POP by $0.28 \%$. 
Gravity Model Approach using Vector Autoregression in Indonesian Plywood Exports

Table 4. Impulse Response Function of GDP

\begin{tabular}{ccccccc} 
Period & S.E. & VOLUME & GDP & ER & PRICE & POPULATION \\
\hline \hline 1 & 50965.41 & 0.007087 & 99.99291 & 0.000000 & 0.000000 & 0.000000 \\
2 & 52123.60 & 0.010891 & 95.63597 & 1.663729 & 2.404909 & 0.284505 \\
3 & 52963.30 & 0.055252 & 92.76976 & 2.609712 & 4.052058 & 0.513216 \\
4 & 53640.64 & 0.095558 & 90.52864 & 3.243443 & 5.404768 & 0.727588 \\
5 & 54186.62 & 0.131806 & 88.77990 & 3.655988 & 6.508247 & 0.924058 \\
6 & 54626.49 & 0.164004 & 87.40542 & 3.918245 & 7.410418 & 1.101908 \\
7 & 54980.44 & 0.192418 & 86.32043 & 4.078793 & 8.147471 & 1.260888 \\
8 & 55264.74 & 0.217314 & 85.46163 & 4.171499 & 8.748266 & 1.401291 \\
9 & 55492.60 & 0.238964 & 84.78094 & 4.219987 & 9.236263 & 1.523847 \\
10 & 55674.74 & 0.257646 & 84.24125 & 4.240661 & 9.630823 & 1.629615 \\
\hline \hline
\end{tabular}

Source: Data processed with Eviews

\subsection{Variance Decomposition of Population}

In period 10 , the estimated population variance error was $95.78 \%$, followed by $\mathrm{P}$ by $2.97 \%$, ER by $0.57 \%$, Vol by $0.59 \%$, and GDP by $0.07 \%$.

Table 5 Impulse Response Function of Population

\begin{tabular}{|c|c|c|c|c|c|c|}
\hline Period & S.E. & VOLUME & GDP & PRICE & PRICE & POPULATION \\
\hline \hline 1 & $2.11 \mathrm{E}+08$ & 0.003029 & 0.032579 & 1.554577 & 5.951890 & 92.45792 \\
2 & $2.84 \mathrm{E}+08$ & 0.108791 & 0.097282 & 1.136796 & 4.668425 & 93.98871 \\
3 & $3.32 \mathrm{E}+08$ & 0.190079 & 0.086959 & 0.880454 & 3.737453 & 95.10506 \\
4 & $3.67 \mathrm{E}+08$ & 0.258832 & 0.073107 & 0.721893 & 3.089361 & 95.85681 \\
5 & $3.94 \mathrm{E}+08$ & 0.322297 & 0.063472 & 0.630413 & 2.685918 & 96.29790 \\
6 & $4.15 \mathrm{E}+08$ & 0.382555 & 0.059028 & 0.583514 & 2.486805 & 96.48810 \\
7 & $4.33 \mathrm{E}+08$ & 0.440067 & 0.058982 & 0.564375 & 2.451802 & 96.48477 \\
8 & $4.48 \mathrm{E}+08$ & 0.494775 & 0.062143 & 0.560833 & 2.543118 & 96.33913 \\
9 & $4.60 \mathrm{E}+08$ & 0.546477 & 0.067364 & 0.564548 & 2.726954 & 96.09466 \\
10 & $4.71 \mathrm{E}+08$ & 0.594974 & 0.073690 & 0.570193 & 2.974293 & 95.78685 \\
\hline \hline
\end{tabular}

Source: Data processed with Eviews

\subsection{Variance Decomposition of Price $(P)$}

Based on the research shown in Table 6, the result is that Price $(\mathrm{P})$ in period 1, the estimated variance error is $51.69 \%$, which is explained by the variable $\mathrm{P}$ itself, the other variable that has the most significant influence is ER of $44.57 \%$, and Vol amounting to $3.29 \%$, then the smallest variable that affects GDP is $0.43 \%$, while POP does not affect the P variable in the short term. In period 2, the estimated price variance error $(\mathrm{P})$ is $52.95 \%$ which is explained, by the variable itself. Other variables that most affected were ER by $42.41 \%$ and followed by Vol by $2.34 \%$, then $2.27 \%$. The smallest other variables affect the POP by $0.02 \%$. In period 10 , the estimated price variance $(\mathrm{P})$ is $60.36 \%$ which is explained by the variable itself. The other variable that has the most influence on $\mathrm{P}$ is ER by $33.93 \%$, then followed by GDP by $3.08 \%$, and Vol by $1.89 \%$ while the smallest variable affecting P is POP by $0.71 \%$. 
Anwar Sanusi, Rusiadi, M. Isa Indrawan, Irma Fatmawati, Ade Novalina, Samrin, Andysah Putera Utama Siahaan, Saimara Sebayang, Marahadi Siregar, Ahmad Taufik

Table 6. Impulse Response Function of Price

\begin{tabular}{|c|c|c|c|c|c|c|}
\hline Period & S.E. & VOLUME & GDP & ER & PRICE & POPULATION \\
\hline \hline 1 & 1198.397 & 3.292311 & 0.434806 & 44.57959 & 51.69329 & 0.000000 \\
2 & 1588.409 & 2.342371 & 2.271150 & 42.41161 & 52.95316 & 0.021710 \\
3 & 1837.034 & 2.022359 & 2.728026 & 40.80044 & 54.37141 & 0.077767 \\
4 & 2010.197 & 1.896993 & 2.931646 & 39.38300 & 55.63239 & 0.155972 \\
5 & 2135.603 & 1.848887 & 3.029991 & 38.12799 & 56.74499 & 0.248138 \\
6 & 2228.330 & 1.836979 & 3.077307 & 37.02276 & 57.71574 & 0.347215 \\
7 & 2297.711 & 1.843288 & 3.097094 & 36.05911 & 58.55301 & 0.447496 \\
8 & 2349.976 & 1.858745 & 3.101329 & 35.22890 & 59.26646 & 0.544570 \\
9 & 2389.488 & 1.878352 & 3.096746 & 34.52298 & 59.86669 & 0.635230 \\
10 & 2419.400 & 1.899210 & 3.087378 & 33.93116 & 60.36491 & 0.717346 \\
\hline \hline
\end{tabular}

Source: Data processed with Eviews

\subsection{Variance Decomposition of Volume (Vol)}

Based on the results of the research shown in Table 7, the results show that the Lapis Indonesia Export Volume ( $\mathrm{Vol}$ ) in period 1, the estimated variance error is $100 \%$ which is explained by the variable itself. While the variables of GDP, ER, P, and POP do not affect Plywood Export Volume. In period 2, the estimated variance error is $99.47 \%$ which is explained by the variable itself. Variables that affect Vol are P by $0.39 \%$ and followed by POP by $0.10 \%$, then GDP by $0.02 \%$, and ER by $0.005 \%$. In period 10 , the estimated variance error is $97.69 \%$ which is explained by the variable itself. The variable that most influences is $\mathrm{P}$ at $1.61 \%$. Then followed by the smallest variables affecting Vol, such as POP by $0.43 \%$, ER by $0.21 \%$, then GDP by $0.02 \%$.

Table 7. Variant Decomposition of Indonesian Plywood Export Volume (Vol)

\begin{tabular}{|c|c|c|c|c|c|c|}
\hline Period & S.E. & VOLUME & GDP & ER & PRICE & POPULATION \\
\hline \hline 1 & 11202.25 & 100.0000 & 0.000000 & 0.000000 & 0.000000 & 0.000000 \\
2 & 11275.47 & 99.47766 & 0.023320 & 0.005303 & 0.393286 & 0.100429 \\
\hline 3 & 11304.44 & 99.00981 & 0.025833 & 0.015031 & 0.754941 & 0.194385 \\
4 & 11326.29 & 98.64809 & 0.027030 & 0.031551 & 1.026048 & 0.267277 \\
5 & 11343.07 & 98.37117 & 0.027468 & 0.054353 & 1.224616 & 0.322396 \\
6 & 11355.99 & 98.15890 & 0.027550 & 0.082336 & 1.367868 & 0.363344 \\
7 & 11365.95 & 97.99567 & 0.027511 & 0.114121 & 1.469508 & 0.393186 \\
8 & 11373.66 & 97.86956 & 0.027492 & 0.148291 & 1.540208 & 0.414453 \\
9 & 11379.65 & 97.77148 & 0.027566 & 0.183533 & 1.588218 & 0.429208 \\
10 & 11384.35 & 97.69455 & 0.027764 & 0.218711 & 1.619861 & 0.439115 \\
\hline \hline
\end{tabular}

Source: Data processed with Eviews

Based on the explanation of the results of variance decomposition, it is known that the policy for the Indonesian government to be able to focus Plywood Exports to several countries that have a high amount of population and Gross Domestic Product (GDP) will make Indonesia's foreign exchange reserves a surplus and the Rupiah exchange rate will also appreciate. 


\section{CONCLUSIONS}

The estimation results using Vector Autoregression (VAR), shows the results of the relationship between GDP, POP, ER, P, Dt and Vol with lag 1, it can be concluded that by observing the t-statistics of each coefficient, the reciprocal relationship between the variables of GDP, POP, ER, P, Dt, and Vol are statistically significant. Another variable besides the variable itself that has the most significant contribution to GDP is the Distance (Dt) $t-1$. The variable that has the most significant contribution to the population other than the population itself is Price $(\mathrm{P}) \mathrm{t}-1$. The variable that has the most significant contribution to ER besides the ER variable itself is Population. The variable that has the most significant contribution to Price (P) is the GDP variable. Other variables that have the most significant contribution to distance (Dt) other than the distance variable (Dt) itself are variables of Indonesian Plywood Export Volume (Vol). Other variables that have the most significant contribution to Indonesia's Lapis Export Volume ( $\mathrm{Vol})$ in addition to Indonesia's Lapis Export Volume variable (Vol) itself are Population. Based on the results of the Impulse response function, it is known that the first stability of all variables is in the 15 th or medium term period and the second stability is in the 65 or long-term period, it means that even though there are shortterm variables that have no effect but in the medium and long-term interplay. From the results of variance decomposition, overall both in the long run and in the short term, all variables in the first period are affected by the variable error variance itself. While in the long run there is a change in the effect of the decreasing variance error on the variable itself and shifted by other variables. Estimation of the other variable error variance that most influences GDP is Dt period 1, Estimating other variable variance errors that most affect POP is Dt in period 3; Estimating other variable variance errors that most affect ER is ER up to the long-term period of 120, Estimated Another variable variance error that most influences $\mathrm{P}$ in the long run in period 120 is POP; Estimated variance error of other variables that most influence Dt in the medium term is long-term POP. Estimates of other variable variance errors that most affect Vol, in the long run, are POP.

\section{REFERENCES}

[1] A. Ikhwan, M. Yetri, Y. Syahra, and J. Halim, "A Novelty of Data Mining for Promoting Education based on FP-Growth Algorithm," Int. J. Civ. Eng. Technol., vol. 9, no. 7, pp. 1660-1669, 2018.

[2] M. D. T. P. Nasution, Y. Rossanty, P. B. Sari, and A. P. U. Siahaan, "Online Shoppers Acceptance: an Exploratory Study,” Int. J. Civ. Eng. Technol., vol. 9, no. 6, pp. 793-799, 2018.

[3] T. Eddy, B. Alamsyah, S. Aryza, and A. P. U. Siahaan, "An Effect Phenomena Circle Living Field in Secanggang Langkat," Int. J. Civ. Eng. Technol., vol. 9, no. 7, pp. 15751580, 2018.

[4] Rusiadi et al., "Simultaneous Response of Dividend Policy and Value of Indonesia Manufacturing Companies An Approach of Vector Autoregression," Int. J. Civ. Eng. Technol., vol. 9, no. 6, pp. 313-323, 2018.

[5] D. Siregar et al., "Multi-Attribute Decision Making with VIKOR Method for Any Purpose Decision,” J. Phys. Conf. Ser., vol. 1019, p. 012034, Jun. 2018.

[6] Y. Rossanty, S. Aryza, M. D. T. P. Nasution, and A. P. U. Siahaan, "Design service of QFD and SPC methods in the process performance potential gain and customers value in a company," Int. J. Civ. Eng. Technol., vol. 9, no. 6, 2018. 
Anwar Sanusi, Rusiadi, M. Isa Indrawan, Irma Fatmawati, Ade Novalina, Samrin, Andysah Putera Utama Siahaan, Saimara Sebayang, Marahadi Siregar, Ahmad Taufik

[7] M. D. T. P. Nasution, Y. Rossanty, A. P. U. Siahaan, and S. Aryza, "The Phenomenon of Cyber-Crime and Fraud Victimization in Online Shop," Int. J. Civ. Eng. Technol., vol. 9, no. 6 , pp. 1583-1592, 2018.

[8] S. Aryza, M. Irwanto, Z. Lubis, A. P. U. Siahaan, R. Rahim, and M. Furqan, "A Novelty Design of Minimization of Electrical Losses in A Vector Controlled Induction Machine Drive," in IOP Conference Series: Materials Science and Engineering, 2018, vol. 300, no. 1.

[9] A. P. U. Siahaan, Rusiadi, P. L. E. Kan, K. N. F. K. Azir, and A. Amir, "Prim and Genetic Algorithms Performance in Determining Optimum Route on Graph," Int. J. Control Autom., vol. 11, no. 6, pp. 109-122, 2018.

[10] A. P. U. Siahaan, "Rabin-Karp Elaboration in Comparing Pattern Based on Hash Data," Int. J. Secur. Its Appl., vol. 12, no. 2, pp. 59-66, Mar. 2018.

[11] A. P. U. Siahaan et al., "Combination of Levenshtein Distance and Rabin-Karp to Improve the Accuracy of Document Equivalence Level," Int. J. Eng. Technol., vol. 7, no. 2.27, pp. 17-21, 2018.

[12] V. N. S. Lestari, H. Djanggih, A. Aswari, N. Hipan, and A. P. U. Siahaan, "Technique for order preference by similarity to ideal solution as decision support method for determining employee performance of sales section," Int. J. Eng. Technol., vol. 7, no. 2.14 Special Issue 14, 2018.

[13] B. Seyoum, "Revealed comparative advantage and competitiveness in services," J. Econ. Stud., vol. 34, no. 5, pp. 376-388, Oct. 2007.

[14] Dwiprabowo, Produksi Olahan Kayu di Pasar Dunia. Jakarta, 2009.

[15] BI, "Laporan Kebijakan Moneter," Bank Indonesia, 2018. [Online]. Available: https://www.bi.go.id/id/Default.aspx.

[16] W. Bank, "Export Competitiveness, Regional Trade Integration Could Spur South African Export Growth," The World Bank, 2013. [Online]. Available: http://www.worldbank.org//.

[17] L. A. Beaulieu, "The Weathering of Moulded Plywood Components," Aircr. Eng. Aerosp. Technol., vol. 20, no. 6, pp. 171-186, Jun. 1948.

[18] M. A. Aljarrah, "The Composition of Government Expenditure and Investment in Saudi Arabia: Is it Attractive or Repulsive Relationship?," J. Econ. Adm. Sci., vol. 25, no. 2, pp. 1-18, Dec. 2009.

[19] R. C. Hook and M. R. Czinkota, "EXPORT ACTIVITIES AND PROSPECTS OF HAWAIIAN FIRMS," Int. Mark. Rev., vol. 5, no. 4, pp. 51-57, Apr. 1988.

[20] A. Focacci, "Empirical analysis of the relationship between total consumption-GDP ratio and per capita income for different metals," Int. J. Soc. Econ., vol. 34, no. 9, pp. 612-636, Aug. 2007.

[21] [21] W. S. Purba et al., "Relationships Among Knowledge, Attitude and Behavioral Intention of Waste Management Technology," Int. J. Civ. Eng. Technol., vol. 9, no. 9, pp. 792-798, 2018.

[22] P. J. Sellers, "Strategy and background in congressional campaigns," Am. Polit. Sci. Rev., vol. 92, no. 1, pp. 159-171, 1998.

[23] A. I. F. Lubis et al., "Strategy for Improving Science and Welfare through Community Empowerment Technology," Int. J. Civ. Eng. Technol., vol. 9, no. 9, pp. 1036-1046, 2018.

[24] S. Gouveia, J. Rebelo, and L. Lourenço-Gomes, "Port wine exports: a gravity model approach," Int. J. Wine Bus. Res., vol. 30, no. 2, pp. 218-242, Jun. 2018. 
Gravity Model Approach using Vector Autoregression in Indonesian Plywood Exports

[25] C. Turnip, Skripsi: Analisis Faktor-Faktor yang Mempengaruhi Penawaran Ekspor dan Aliran Perdagangan Kopi Indonesia. Bogor: Departemen Sosial Ekonomi Pertanian. Fakultas Pertanian, nstitut Pertanian Bogor, 2002.

[26] Khairul et al., "Effect of Matrix Size in Affecting Noise Reduction Level of Filtering," Int. J. Eng. Technol., vol. 7, no. 3, pp. 1272-1275, 2018.

[27] R. Rahim et al., "Technique for Order of Preference by Similarity to Ideal Solution (TOPSIS) method for decision support system in top management," Int. J. Eng. Technol., vol. 7, no. 3.4, pp. 290-293, 2018.

[28] J. VANDERKAMP, "The Gravity Model And Migration Behaviour: An Economic Interpretation," J. Econ. Stud., vol. 4, no. 2, pp. 89-102, Feb. 1977.

[29] S. Suroso et al., "Autoregression Vector Prediction on Banking Stock Return using CAPM Model Approach and Multi-Factor APT," Int. J. Civ. Eng. Technol., vol. 9, no. 9, pp. 1093-1103, 2018.

[30] A. Sanusi et al., "GCG Simultaneity Effects, Profit Management And Value Of Indonesian Retail Companies," Int. J. Civ. Eng. Technol., vol. 9, no. 7, pp. 1506-1518, 2018.

[31] Rusiadi et al., "Dependence of poverty dependence on Indonesian economic fundamentals: Sfavar approach," Int. J. Civ. Eng. Technol., vol. 9, no. 6, 2018.

[32] D. Ruslan, Rusiadi, A. Novalina, and A. I. F. Lubis, "Early Detection Of The Financial Crisis Of Developing Countries," Int. J. Civ. Eng. Technol., vol. 9, no. 7, pp. 584-597, 2018.

[33] Rusiadi, Ramli, D. Ruslan, and R. Ginting, "Monetary Transmission Of State Emerging Markets Line Asset Prices: Inflation Control Leading Indicators," Int. J. Civ. Eng. Technol., vol. 9, no. 7, pp. 698-707, 2018.

[34] M. Putri, P. Wibowo, S. Aryza, A. P. U. Siahaan, and Rusiadi, "An Implementation of A Filter Design Passive LC In Reduce a Current Harmonisa," Int. J. Civ. Eng. Technol., vol. 9, no. 7, pp. 867-873, 2018. 